
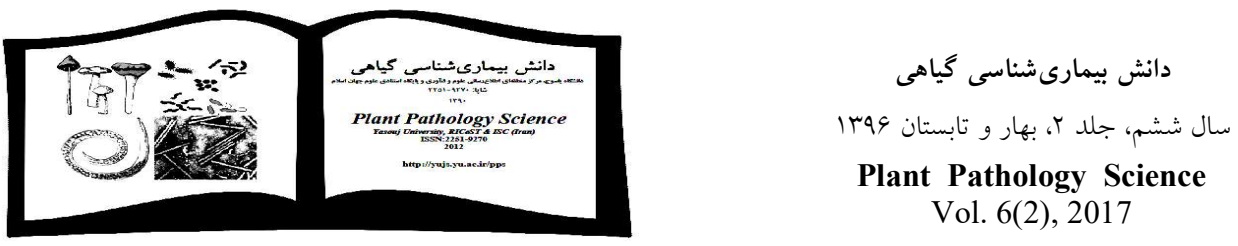

Plant Pathology Science Vol. 6(2), 2017

\title{
Integrated Management of Gray Mold Disease
}

\author{
MARYAM MIRTALEBI and REZA MOSTOWFIZADE-GHALAMFARSA ${ }^{\bowtie}$ \\ Department of Plant Protection, Shiraz University, Shiraz, Iran \\ ( $\triangle$ Corresponding author: rmostofi@shirazu.ac.ir)
}

Received: 30.06 .2016

Accepted: 21.02.2017

Mirtalebi M. \& Mostowfizade-Ghalamfarsa R. 2017. Integrated management of gray mold disease. Plant Pathology Science 6(2):43-54.

Abstract: Gray mold caused by Botrytis cinerea, is one of the most important postharvest diseases on fresh fruits and vegetables worldwide. The disease may start in the field and remain as a latent infection and then develop after harvest, during transportation, packaging, storage and marketing. Nowadays, application of fungicides is the main strategy to control the gray mold disease in conventional agriculture. The presence of fungicide residues in edible fruits and vegetables is a concern for consumers because pesticides are known to have potential harmful effects. Therefore, the search on finding the safe and effective disease control strategies has been accelerated. Integrated management of the disease by using some methods like optimal method of irrigation and fertilization, biological control, use of bioagents, disinfection of fresh fruits and vegetables after harvesting, storing and shipping in a cool and dry condition with low humidity and suitable ventilation are suggested.

Key words: Postharvest disease, Strawberry, Grape, Botrytis

$$
\begin{aligned}
& \text { مديريت تلفيقى بيمارى كيك خاكسترى } \\
& \text { مريم ميرطالبى و رضا مستوفىزاده قلمفرسا هـ } \\
& \text { بخش كياهيزشكى، دانشعاه شيراز، شيراز }
\end{aligned}
$$

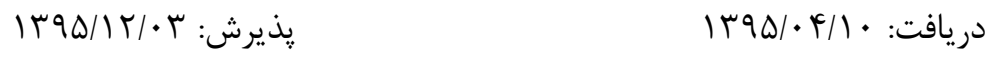

$$
\begin{aligned}
& \text { ميرطالبى م. و مستوفىزاده قلمفرسا ر. و૧ाا. مديريت تلفيقى بيمارى كيك خاكسترى. دانش } \\
& \text { بيمارىشناسى كياهى \&(Y): } \\
& \text { جكيده: بيمارى كيك خاكسترى ناشى از قـارج Botrytis cinerea يكىى از مهـهمترين بيمـارىهـاى يسـ از } \\
& \text { برداشت ميوهها و سبزىهاى تازه در سراسر جهان است. بيمارى مىتواند در مزرعه شروع شود، بهصورت نهفته } \\
& \text { باقى بماند يا ٍِ از برداشت در مراحل حملونقل، بستهبندى، ذخيرهسازى و بازاريـابى كسـترش پيـدا كنـد. } \\
& \text { امروزه در كشاورزى رايج اولين راهبرد براى مهار بيمارى، استفاده از سـموم شـيميايى اسـت، ولـى نكرانىى از }
\end{aligned}
$$

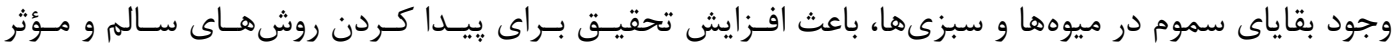

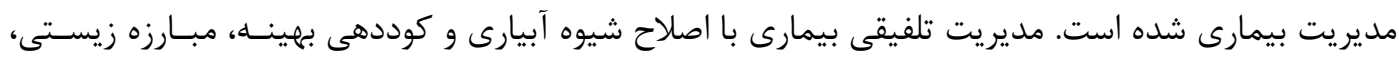

$$
\begin{aligned}
& \text { استفاده از مواد حياتى، ضدعفونى ميوهها يس از برداشت ، نتحهدارى وحمل ميوهها در انبار و كانتينر بـا هـواى } \\
& \text { خنك، رطوبت كم و تهويه مناسب ييشنهاد شده است. } \\
& \text { وازههاى كليدى: بيمارى يس از برداشت، توتفرنكَى، انگور،Botrytis }
\end{aligned}
$$

هـ 
بر اساس برآورد سازمان خواروبار كشاورزى ملل متحد در سراسر جهان، به يك سوم از محصولات غذايى يس از برداشت خسارت وارد مىشود (Gastavsson et al. 2011). بخش مهمى از اين خسارت به دليل بيمارىها است. حملهى بيمارگرها ممكن است در طول زمان برداشت، انباردارى، بازاريابى و حتى يس از خريد توسط مصرفكنند بيماركرهاى غدهها، ميوهها، بركها و گلها در گياهان زينتى، سبزىها و ديخر محصولات مهرم كشاورزى با گَسترش جهانى است و با ايجاد كֶى خاكسترى از مهمترين عوامل يوسيدگىهاى يس از برداشت محسوب مىشود (Elad et al. 2015). دليل اهميت اين بيمارگر در بيمارىهاى يس از برداشت اين است كه شرايط غالب در جرخهى پِ از برداشت مانند زخمها، رطوبت زياد، پِير شدن بافت كَاهان، افزايش اتيلن و ميزان قند بالا همكى زمينهى لازم را براى فعاليت اين قارج فراهم مى كنند. B. cinerea باعث خسارت زياد در تعداد زيادى از ميوههاى تازه مانند سيب، انواع توتها مانند توتفرنغى، تمشك، انگور، خرمالو، كيوى، كلابى و انار مىشود (شكل ()). B. cinerea مستقر شود. اين نوع بقا بهخوبى در توتفرنكى مشاهده مىشود و بيمارگر روى بركهاى مرده زمستان كذرانى مى كند، سيس فاز انگلى خود را در مرحلهى گل دههى آغاز مى كند و بهصورت نهفته روى برجهم و زير كاسبرى باقى مىماند و نزديك يا بلافاصله يس از برداشت، ميوه را آلوده مى كند (Powelson 1960). به همين دليل گاهى آلودگىها در ميوهى توتفرنكى از نزديك كاسبرى كه اغلب زير باقيماندهى گل قرار دارد يا از كلبرگهاى آلوده منشأ مى گيرد. همجنين B. cinerea قادر به آلوده كردن ميوهها و سبزىها يس از برداشت از طريق بافتهاى آسيبديدهى انتهاى ساقهى سرشار از تراوهى غذايى (Nutrient exudates) است و سيس آلودگى انتهاى ساقه به تمام ميوه گسترش مى يابد. اين مدل آلودگى اغلب در ميوهى كيوى مشاهده مىشود (Michailides \& Elmer 2000). در ميوهى سيب آلودگى به كيك سيب از زخمها، انتهاى ساقه يا كاسهى كلٍ انتهاى ميوهها آغاز مىشود (Xiao \& Kim 2008). 

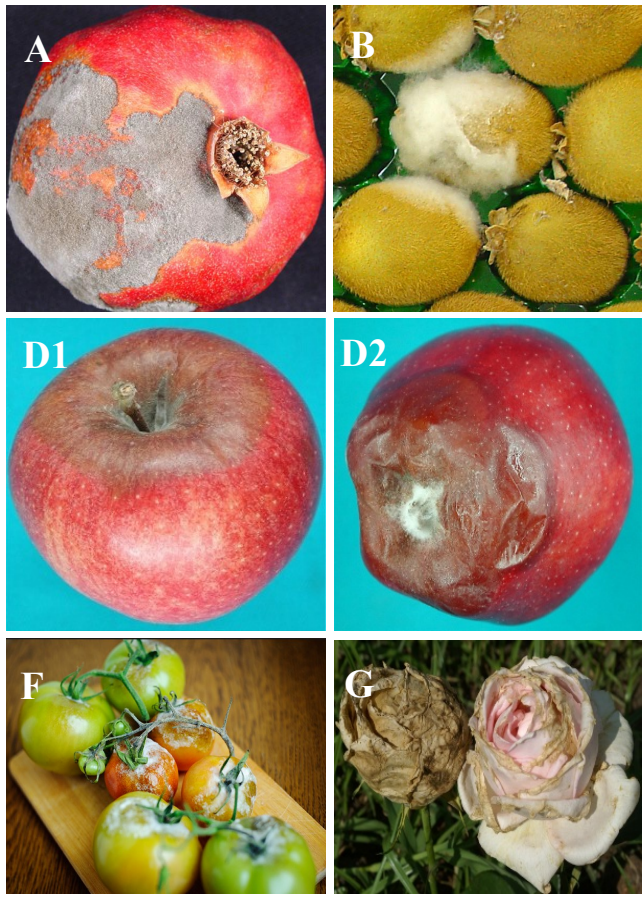
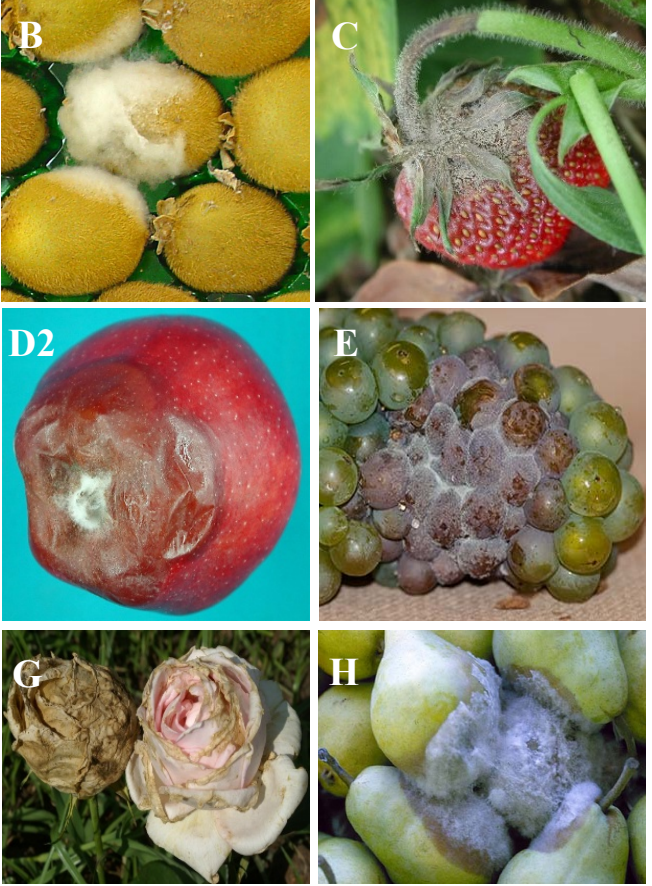

شكل ا- بيمارى كيك خاكسترى ناشى از Botrytis cinerea روى برخى محصولات. A: انار، B: كيوى، C: توتفرنكى، D: سيب(D1: شروع كيك خاكسترى از انتهاى ساقه، D2: شروع كيك خاكسترى از كاسهى

$$
\text { كَلِ إنتهاى ميوه)، E: انكَور، F: كَوجهفرنكَى، G: كَل رُز، H: كَلابى. }
$$

Figure 1. Gray mold diseases caused by Botrytis cinerea on some crops. A: Pomegranate, B: Kiwi fruit, C: Strawberry, D: Apple (D1: Gray mold originating from stem-end, D2: Gray mold originating from calyx-end), E: Grape, F: Tomato, G: Rose, H: Pear.

يكى از مههمرين بيمارىهاى پس از برداشت در ايران ، بيمارى كيك خاكسترى ناشى از Botrytis cinerea از برداشت آمار دقيقى وجود ندارد. اما آنجه مسلم است از بيماركرهاى مههم پِ از برداشت كياهانى مانند رز،

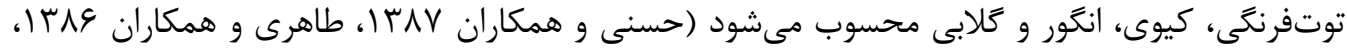
.(Mosayyebzadeh et al. 2009, Khazaeli et al. 2010, Naeimi \& Zare 2014 براى مديريت بيمارى يوسيدكى خاكسترى در كشاورزى رايج (Conventional agriculture)، استفاده از قارجكشهاى شيميايى است. هماكنون در سراسر جهان كشاورزان به دلايل مختلف مانند وجود بقاياى سم، ايجاد جدايههاى مقاوم و همجنين مشكلات زيستمحيطى مايل به استفاده از رويكردهاى جايگزين بهصورت 
تيمارهاى بلهنهايى (Stand-alone treatment) در كشاورزى اركانيك (Organic agriculture) يا همراه با قارجكشهاى شيميايى هستند (Romanazzi et al. 2012). 1- مديريت كيك خاكسترى در محصولات انبارى ميوهها بلافاصله يُ از برداشت بايد در جاى خنك قرار گيرند تا اولاً گرماى حاصل از مزرعه از بين برود و ثانياً تنفس و از دست دادن آب كاهش يابد و كيفيت محصول حفظ شود (Elad et al. 2015). اين روش خصوصاً در مناطق گرم بسيار مهمم است. زيرا كاهش آب كه از ساقها و كلبرگها شروع و باعث تشديد فرايند پِير شدن مىشود، در اين مناطق شديد است. همجنين دما در طول زمان انباردارى بايد بهينه و ثابت باشد. زيرا هر گونه عدم ثبات در دماى انباردارى باعث فعال شدن بيماركر نهفته، خصوصاً در جابهجايىهاى طولانى مىشود. انكور معمولاً بهصورت مستقيم در مزرعه بستهبندى مىشود دليل اين كار به حداقل رساندن ميزان از بين رفتن يوشش مومى طبيعى سطح ميوه به دليل جابجايىهاى مكرر و همهنين كاهش ميزان جدا شدن حبهها از خوشه است. ميوهها سيس با استفاده از اتاقهاى تهويهى هوا در يك شرايط يِش خنك كردن קندساعته قرار مى گيرند تا دماى آنها به صفر تا يك درجهى سلسيوس برسد. اگر جريان هواى سرد متوقف شود و يا ميوههاى خنك در شرايط ترم قرار گيرند باعث ميعان مىشود. اين رطوبت بالا و آب آزاد، موجب افزايش جوانهزنى كنيديومها و نفوذ آنها به ميوه از طريق زخممهاى ناشى از برداشت و ايجاد آلودگى مىشود سيس با تماس مستقيم ميوهها و يا ميسيليومهاى هوايى، ميوههاى سالم مجاور را نيز آلوده كند. اين نوع آلودَى را آلودگى تودرتو يا آشيانهاى مى گويند (Romanazzi et al. 2016). در بسيارى از كشورهاى ارويايى استفاده از قارجكشهاى شيميايى براى مبارزه با بيماركرهاى پس از برداشت بسيارى از محصولات كشاورزى ممنوع است. در انكور و برخى از ميوههاى ديخر استفاده از دى اكسيد گوگرد در طول انباردارى مجاز است. يس از مشخص شدن دىاكسيد گوگرد بهعنوان يك آفت كش، به دليل Maximum residue limits = ايجاد واكنش فوق حساسيت در انسان، ميزان حد مجاز باقيماندهى بيشينه آن • إن ميلى (MRLs كشاورزان مزارع اركانيك از تدخين ازن يس از برداشت استفاده مى كنند. استفاده از ازن به دليل داشتن Karaca et al. ) فعاليت اكسيدكنندگى آن مىتواند باعث كاهش باقيماندهى قارجكشها روى ميوهها شود 
2012, Mlikota Gabler et al. 2010 به دليل مشكلات استفاده از دىاكسيد گَگَرد مواد جايكزينى توصيه شده است. بهعنوان مثال كاربرد اتانول قبل از برداشت (Karabulut et al. 2003)، اتانول همراه با كيتوزان يا كلريد كلسيم (Romanazzi et al. 2007, Chervin et al. 2009)، استفاده از نمكهاى آلى ( Khamis \& (Controlled or modified atmospheres) 2014 (نباردارى در اتمسفر تحت كنترل يا تعديلشده (Crisosto et al. 2002) تعداد كمى از اين روشها در سطح وسيع و تجارتى استفاده مىشود (Romanazzi et al. 2012).

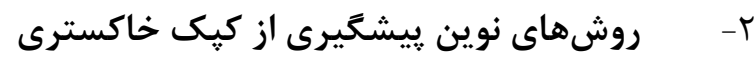

$$
\text { روشهاى نوين پيشگيرى از خسارت كيك خاكسترى عبارتند از: }
$$

1-r- اصلاح شيوه آبيارى و كوددهى بهينه : براى كاهش آلودكى انكور به كيك خاكسترى بايد در بـاغ از آبيارى بارانى و استفاده بيش از حد نياز كودهاى نيتروزنه يرهيز كرد. جون هر دو عامل بـر فيزيولـوزى كيـاه، كيفيت ميوه و حساسيت ميوهها به يوسيدگى تأثير دارند. استفاده از نيترات آمونيوم به ميـزان • لها كيلـوكرم در هكتار در خاكهاى با اسيديته بالاو همجنين آبيارى تاكستانهـا در تبخيـر • • درصـد توصسيه مسىشـود (Thomidis et al. 2016) r-r- مبارزه زيستى : براى حفاظت محصول از آلودىى به B. cinerea كاربرد بعضى ريزجانداران متعارض، قبل از برداشت آن پِيشنهاد شده است (Feliziani \& Romanazzi 2013, Mari et al. 2014). در يزوهشى براى مشخص كردن اثر سيستم كشت روى جمعيت ميكروبى رورُست انكور، درر تاكستانهاى اركانيك افزايش جمعيت قارج متعارض Aureobasidium pullulans (de Bary \& Löwenthal) G. Arnaud كزارش شده است(Schmid et al. 2011). Aullulans در نقش مادهى مؤثر در فرآوردهاى زيستى، با نامهاى تجارتى بونيويروتكت و بوتِتور، بيوفِرم، تيولن و آستريا براى مبارزه با B. cinerea به بازار عرضه شده است. تحقيق روى عوامل مهار زيستى براى استفادهى يس از برداشت موجب توليد محصولات تجارتى مختلفى شده

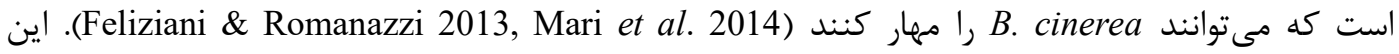
محصولات مانند (شِمِر، كاندىفروت، بونىٍِروتكت، يلد پِلاس، نِكسى، پِانتوويتال، بيوسِيو) وارد بازار نيز شدهاند 
Feliziani \& Romanazzi 2013, Mari et al. 2014) خاكسترى با استفاده از قارجها و باكترىهاى مختلف انجام شده است. در آزمايش كشت متقابل، اغلب جدايههاى بومى .Trichoderma spp روى يركنهى B. cinerea جداسازى شده از توتفرنكى هاى آلوده، رشد كردند و با توليد هاگهاى فراوان سختينههاى بيماركر را تجزيه كردهاند. همجنين آزمون گلخانهاى با استفاده از اين متعارضها، نشان داد كه درصد آلودگى در كليهى تيمارها در مقايسه با شاهد كاهش يافته است Trichoderma asperellum Samuels, Lieckf. \& Nirenberg تركيبات فرار (Naeimi \& Zare 2014) بازدارندگى رشد ميسليوم و جوانهزنى كنيديوم B. cinerea و مهار يوسيدگى يس از برداشت ناشى از كيك خاكسترى در ميوهى توتفرنغى در شرايط آزمايشگاه شده است (جلالى و ظفرى سوسا). تركيب جند Pichia , Candida membranifacien (Lodder \& Kreger-van Rij) Wick جدايهى مخمرهاى guilliermondi Wick \& Burton. خاكسترى در نتيجهى افزايش فعاليت آنزيم يراكسيداز و تركيبات فنلى در ميوهى سيب شده است ( Zangoei 2013 خيلى كم است، زيرا هزينهى ثبت اين سموم زيستى زياد است و بازار محدود براى آنها وجود دارد. همجنين معمولاً رسيدن از مرحلهى كشف يك متعارض مؤثر به معرفى يك محصول تجارتى تصويبشده و سودآور مشكل است. كاهى كارآيى عامل مهار زيستى تغيير مى كند كه دليل آن ممكن است وجود آلودگى مستقرشده از قبل، ميزان بالاى مايهى قارج بيماركر، شرايط نتحهدارى ضعيف عامل مهار زيستى قبل از كاربرد يا استفاده نامناسب از آنها باشد. اضافه كردن افزودنىهاى مختلف از جمله روشهايى است كه براى افزايش قابليت اجرا، تأثير و قابليت اطمينان به عوامل مهار زيستى ميكروبى گِ از برداشت به كار برده مىشود. تركيب نمكهايى مانند بى كربناتها و كيتوزان براى بهبود اثر عوامل مهار زيستى و پايدارى بيشتر آنها كزارش شده است(Meng et al. 2010, Qin et al. 2015). استفاده از نمكهاى آلى و معدنى مانند كلريد كلسيم قبل از برداشت در برخى سيستمهاى كشت اركانيك براى اين منظور نيز رايج است (Khamis \& Sergio 2014). ץ-r- استفاده از مواد حياتى : تعداد زيادى از تركيبات فرار، تراوهاى گياهى و مواد مشتق شده از حيوانات با خاصيت ضدقارجى گزارش شده است. تركيبات فرار مانند آستالدئيد، بنزالدئيد، بنزيل الكل، إتانول، 
متيل سالسيلات، هَزان، جاسمونات، آليسين، كلوكوزينولات و ايزوتيوسيانات توانستهاند از آلودگى به Tripathi \& ) در محصولات مختلف در شرايط آزمايشگاهى و در مقياس كم جلوكيرى كنند cinerea Dubey 2004

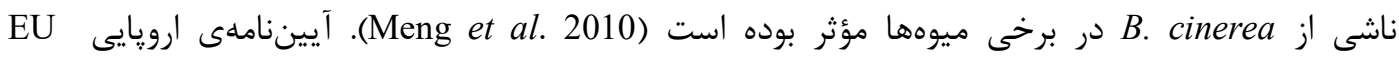
2014/563 از كلريد كيتوزان در فهرست محصولات حفاظت كياهى نام برده است و بنابراين اين ماده از اول

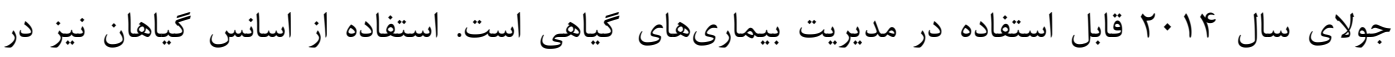
سالهاى اخير براى مهار بيمارى كيك خاكسترى پٍ از برداشت مورد توجه بوده است ( \&ivakumar \& Bautista-Banos 2014 مطالعهى اثر ضدقارجى تراوهى گیاهان ترخون، مرزه، زنيان و بومادران نشان داد كه استفاده از عصارهى • ا درصد بومادران بيشترين اثر بازدارندگى را روى رشد رويشى قارج دارد (اسكندرى و جمالى زواره بوس (). براى استفاده از اسانسها مواردى مانند فرموله كردن (Formulation)، روش كاربرد، امكان كياهسوزى و كيفيت حسى (Organoleptic quality) بايد مورد توجه قرار كيرد. ץ-F- ضدعفونى ميوهها يس از برداشت : مواد عفونتزدا، ماند اتانول، اسيد استيك، آب الكتروليز شده، براى سترونسازى سطح ميوهها قبل از بستهبندى كه ميوه نياز به شستوشو دارد، استفاده مىشود. اسيد استيك و اتانول بلهنوان سموم تدخينى براى مهار يوسيدگى پِ از برداشت انگور استفاده مىشود(Sholberg et al. 1996, Mlikota Gabler et al. 2005). استفاده از آب الكتروليز شده نيز باعث عفونتزدايى آب مورد استفاده در جايخاههاى بستهبندى و همجنين كاهش آلودگى به كنيديومهاى بيماركرهاى مختلف از جمله B. cinerea مىشود. روشهاى مكانيكى مانند يرتو فرابنفش- سى (UV-C)، ازن و اتمسفر تحت كنترل يا تعديلشده نيز براى مهار كيك خاكسترى انكور مؤثر بوده است ( Romanazzi et al 2012). استفاده از برتودهى ملايم با اشعه گاما مىتواند كاملاً باعث غيرفعال شدن B. cinerea در رزهاى شاخه بريده شود. بنابراين استفاده از شدت پايين يرتودهى كاما (دو كيلوكرمى) در تركيب با دى كلروايزوسيانورات سديم كه يك تركيب شيميايى بىخطر است مىتواند بهطور معنىدارى خسارت كيك خاكسترى را در رزهاى شاخه بريده كاهش دهد (Chu et al.2015). در ميان روشهاى فيزيكى استفاده از تيمار گرما نيز مىتواند موثر باشد. زمانى كه ميوههاى توتفرنكى به مدت سه ساعت و نيم در هواى كرم هاf 
درجهى سلسيوس قرار مى گيرند، مقاومت آنها به بيمارى كيك خاكسترى افزايش يِيدا مى كند كه اين افزايش مقاومت در نتيجه كاهش اندازه زخمها، افزايش فعاليت كيتيناز و فنيلآلانينآمونيا-لياز، افزايش مقدار تركيبات فنلى، افزايش آنزيمهاى ضد اكسايشى مانند سويراكسيد ديسموتاز و كاتالاز است (Jin et al. 2016). تيمار يس از برداشت كل شاخه بريده رز با برتو فرابنفش منجر به مهار كيك خاكسترى و افزايش معنىدار دوام عمر گل و تركيبات فنولى در مقايسه با شاهد (بدون يرتوتابى) شد (ياشايى و همكاران سوس (). قرار دادن

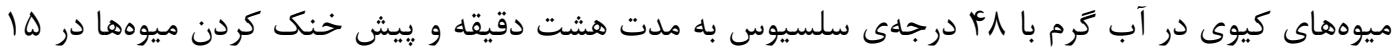
درجهى سلسيوس به مدت ^^ ساعت در رطوبت بالاى •9 درصد باعث كاهش آلودىى به كيك خاكسترى شد (Taheri et al. 2008). استفاده از اتمسفر تعديلشده با تركيب كازى •9 درصد اكسيزن و • ا درصد دىاكسيد كربن توانست ميزان يوسيدكى خاكسترى در انكور رقم شاهرودى را كاهش دهد

.(Mosayyebzadeh et al. 2009)

\section{نتيجه كيرى و وِيشنهاد}

يوسيدگى يُ از برداشت ناشى از كيك خاكسترى از لحاظ اقتصادى بسيار مهمم است و در بعضى موارد باعث از بين رفتن كامل محصول مىشود. در ايران B. cinerea از دامنهى وسيعى از گياهان مانند توتفرنكى، گَوجهفرنگى، كيوى، رُز، مركبات، انكور، سيب، گلابى، به، بادامزمينى، خيار، باقلا، سويا، كلزا، نخود، لوبيا، زيتون، سيبزمينى، يِاز، خرزهره، كل صدتومانى، ميخك، شمعدانى، گَلايول، كَندم و بادامزمينى جداسازى شده است (ارشاد Mirzaee et al. 2008،IN1V). براى مبارزه با بيمارى در ايران از قارجششهايى مانند بردوفيكس، اييروديون+كاربندازيم، مانكوزب، كويراكسى كلريد، كاربندازيم، بنوميل، كايتان، استروبى، كلروتالونيل و زينب استفاده مىشود، كه بيماركر واكنشهاى متفاوتى نسبت به آنها نشان مىدهد (Mavandadi et al. 2016)، ولى هيج يك از آنها نتوانسته است بلهورت قطعى بيمارى را مهار كند (Naeimi \& Zare 2014). جالشهاى مهمى خسارت يوسيدگىهاى پس از برداشت ناشى از كيك خاكسترى را افزايش مىدهد كه از آن جمله مىتوان به استفاده از نهادهاى بى كيفيت و روشهاى زراعى نامناسب، نبودن دانش، مهارت و فناورى لازم براى مراحل مختلف برداشت، بستهبندى و انباردارى (مانند امكانات يِش خنك كردن، فضاهاى خنك با اتمسفر)، نبودن امكانات لازم براى تميز كردن و شستوشوى ميوهها و 
سبزىها، حملونقل ضعيف و غيراستاندارد و نبودن امكانات لازم براى فراورى محصولات كشاورزى اشاره كرد (Rosa 2006). در حال حاضر عمومىترين روش مهار بيمارى در مزرعه، باغ يا سالنهاى يرورش كَاهان حساس، قارجكشهاى شيميايى است ولى در بسيارى از كشورها اجازمى استفاده از اين سموم يس از برداشت داده نمىشود. ادامهى استفاده از اين قارجكشها قبل از برداشت هم در حال بررسى موشكافانه است، كه اين امر ضرورت گسترش مهار بيمارىهاى يس از برداشت، بدون استفاده از قارجكشهاى رايج را نشان مىدهد. بنابراين راهبردهاى جايكزين شامل مديريت تلفيقى با اصلاح شيوه آبيارى و كوددهى بهينه، مبارزه زيستى، استفاده از مواد حياتى جانداران، ضدعفونى ميوهها پِ از برداشت ، نگَهدارى وحمل ميوهها در انبار و كانتينر با هواى خنك، رطوبت كم و تهويه مناسب براى پيشكيرى يا كاهش خسارت بيمارى يیشنهاد مىشود.

References

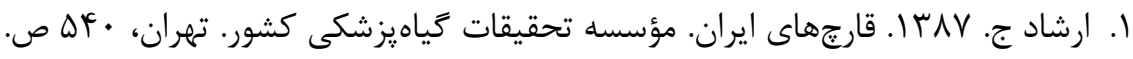

ז. اسكندرى الف. و جمالى زواره ع. سوץ". مطالعه اثر ضدقارجى عصاره جهار گياه در كنترل قارجهاى انبارى. خلاصه مقالات بيست و يكمين كنكره كياهيزشكى ايران، مؤسسه تحقيقات گياهيزشكى كشور،

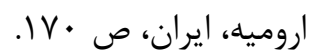

ז. ياشايى ا.، ناظرى دلجو م. ج. و خضرىنزاد ن. سوسا. بررسى اثر پرتوتابى نور ماوراءبنفش-سى (Ultraviolet-C) مقالات بيست و يكمين كنگره كَياهيزشكى ايران، مؤسسه تحقيقات كَياهيزشكى كشور، اروميه، ايران، ص

†. جلالى ف. و ظفرى د. سوسا. بررسى توانايى تركيبات فرار Trichoderma asperellum در بازدارى از رشد ميسليوم و جوانهزنى كنيدى Botrytis cinerea و كنترل يوسيدگى بوتريتيسى پِ از برداشت ميوه توتفرنگى. خلاصه مقالات بيست و يكمين كنكره گياهيزشكى ايران، مؤسسه تحقيقات گياهيزشكى كشور،

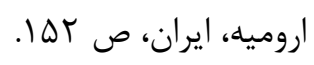

ه. حسنى ا.، جليلى مرندى ر.و قوستا ى. لY I ا. استفاده از اسانسهاى گياهى براى كنترل بيمارى كيك

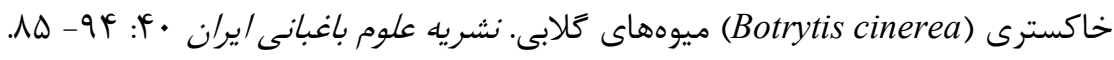




$$
\begin{aligned}
& \text { צ. طاهرى ح.، فاتحى ج.، غلاميان ا. و حلاجى سانى م. ف. ع بـا. استفاده از تيمار آب گرم و پيش سرما در } \\
& \text { مبارزه با بوسيدگى كيوى ناشى از قارج Botrytis cinerea. خلاصه مقالات هجدهمين كنگره كياهيزشكى } \\
& \text { ايران، مؤسسه تحقيقات كياهيزشكى كشور، همدان، ايران، ص ^rr. }
\end{aligned}
$$

7. Chervin C., Lavigne D. \& Westercamp P. 2009. Reduction of gray mold development in table grapes by preharvest sprays with ethanol and calcium chloride. Postharvest Biology and Technology 54:115-117.

8. Chu E. H., Shin E. J., Park H. J. \& Jeong R. D. 2015. Effect of gamma irradiation and its convergent treatment for control of postharvest Botrytis cinerea of cut roses. Radiation Physics and Chemistry 115:22-29.

9. Crisosto C. H., Garner D. \& Crisosto G. 2002. Carbon dioxide-enriched atmospheres during cold storage limit losses from Botrytis but accelerate rachis browning of 'Redglobe' table grapes. Postharvest Biology and Technology 26:181-189.

10.Elad Y., Vivier M. \& Fillinger S. 2015. Botrytis: the Good, the Bad and the Ugly. Pp. 1-15. In: Fillinger S., Elad Y. \& Vivier M. (eds.). Botrytis-the Fungus, the Pathogen and Its Management in Agricultural Systems. Springer, Heidelberg, Germany.

11.Feliziani E. \& Romanazzi G. 2013. Preharvest application of synthetic fungicides and alternative treatments to control postharvest decay of fruit. Stewart Postharvest Review 3:16.

12.Gastavsson J., Cederberg C. \& Sonesson U. 2011. Global Food Losses and Food Waste. Food and Agriculture Organization (FAO) of the United Nations, Rome. 37p.

13.Jin P., Zheng C., Huang Y. P., Wang X. L., Luo Z. S. \& Zheng Y. H. 2016. Hot air treatment activities defense resposes and induces resistance against Botrytis cinerea in strawberry fruit. Journal of Integrative Agriculture 15: 2658-2665.

14.Karabulut O. A., Smilanick J. L., Mlikota Gabler F., Mansour M. \& Droby S. 2003. Nearharvest applications of Metschnikowia fructicola, ethanol, and sodium bicarbonate to control postharvest diseases of grape in central California. Plant Disease 87:1384-1389.

15.Karaca H., Walse S. S. \& Smilanick J. L. 2012. Effect of continuous 0. $3 \mathrm{~mL} / \mathrm{L}$ gaseous ozone exposure on fungicide residues on table grape berries. Postharvest Biology and Technology 64:154-159.

16.Khamis Y. \& Sergio R. R. 2014. Applications of salt solutions before and after harvest affect the quality and incidence of postharvest gray mold of 'Italia' table grapes. Postharvest Biology and Technology 87:95-102. 
17.Khazaeli P., Zamanizadeh H., Moradi B. \& Bayat H. 2010. Morphological and molecular identification of Botrytis cinerea causal agent of gray mold in rose greenhouses in central region of Iran. International Journal of Agricultural Science and Research 1:19-24.

18.Mari M., Di Francesco A. \& Bertolini P. 2014. Control of fruit postharvest diseases: old issues and innovative approaches. Stewart Postharvest Review 1: 1-4.

19.Mavandadi A., Khajehali J. \& Sharifnabi B. 2016. Efficacy of conventional fungicides in controlling tomato grey mold. Journal of Greenhouse Culture Science and Technology 6:181-190.

20.Meng X. H., Qin G. Z. \& Tian S. P. 2010. Influences of preharvest spraying Cryptococcus laurentii combined with postharvest chitosan coating on postharvest diseases and quality of table grapes in storage. LWT-Food Science and Technology 43:596-601.

21.Michailides T.J. \& Elmer P. A. G. 2000. Botrytis gray mold of kiwifruit caused by Botrytis cinerea in the United States and New Zealand. Plant Disease 84:208-223.

22.Mirzaee S., Mohammadi Goltapeh E., Shams-Bakhsh M. \& Safaie, N. 2008. Identification of Botrytis spp. on plants grown in Iran. Journal of Phytopathology 156:21-28.

23.Mlikota Gabler F., Smilanick J. L., Ghosoph J. M. \& Margosan D. A. 2005. Impact of postharvest hot water or ethanol treatment of table grapes on gray mold incidence, quality, and ethanol content. Plant Disease 89:309-316.

24.Mlikota Gabler F., Smilanick J. L., Mansour M. F. \& Karaca H. 2010. Influence of fumigation with high concentrations of ozone gas on postharvest gray mold and fungicide residues on table grapes. Postharvest Biology and Technology 55:85-90.

25.Mosayyebzadeh A., Mostofi Y., Javan Nikkhah M. \& Emam Jome Z. 2009. Evaluation of biochemical changes and gray mold during storage of Shahroodi table grapes under modified atmosphere packaging. Journal of Horticultural Science 22:68-77.

26.Naeimi S. \& Zare, R. 2014. Evaluation of indigenous Trichoderma spp. isolates in biological control of Botrytis cinerea, the causal agent of strawberry gray mold disease. Biocontrol in Plant Protection. 1:55-74.

27.Pearson R. C. \& Goheen A. C. 1988. Compendium of Grape Diseases. APS Press, MN, USA. 93p.

28.Powelson R. L. 1960. Initiation of strawberry fruit rot caused by Botrytis cinerea. Phytopathology 50:491-494.

29.Qin X., Xiao H., Xue C., Yu Z., Yang R., Cai Z. \& Si L. 2015. Biocontrol of gray mold in grapes with the yeast Hanseniaspora uvarum alone and in combination with salicylic acid or sodium bicarbonate. Postharvest Biology and Technology 100:160-167. 
30.Romanazzi G., Karabulut O. A. \& Smilanick J. L. 2007. Combination of chitosan and ethanol to control gray mold of table grapes. Postharvest Biology and Technology 45:134140.

31.Romanazzi G., Lichter A., Mlikota Gabler F. \& Smilanick J. L. 2012. Natural and safe alternatives to conventional methods to control postharvest gray mold of table grapes. Postharvest Biology and Technology 63:141-147.

32.Romanazzi G., Smilanick J. L., Feliziani E. \& Droby S. 2016. Integrated management of postharvest gray mold on fruit crops. Postharvest Biology and Technology 113:69-76.

33.Rosa S. 2006. Postharvest management of fruit and vegetables in the Asia-Pacific region / Asian Productivity Organization. Food and Agricultural Organization (FAO). 312 p. Available online at: http://www.apo-tokyo.org/00e-books/AG-18_PostHarvest/AG18_PostHarvest.pdf

34.Schmid F., Moser G., Müller H. \& Berg G. 2011. Functional and structural microbial diversity in organic and conventional viticulture: organic farming benefits natural biocontrol agents. Applied and Environmental Microbiology 77:2188-2191.

35.Sholberg P. L., Reynolds A. G. \& Gaunce A. P. 1996. Fumigation of table grapes with acetic acid to prevent postharvest decay. Plant Disease 80:1425-1428.

36.Sivakumar D. \& Bautista-Baños S. 2014. A review on the use of essential oils for postharvest decay control and maintenance of fruit quality during storage. Crop Protection 64:27-37.

37.Thomidis T., Zioziou E., Koundouras S., Karagiannidis C., Navrozidis, I. \& Nikolaou N. 2016. Effects of nitrogen and irrigation on the quality of grapes and the susceptibility to Botrytis bunch rot. Scientia Horticulturae 212:60-68.

38.Tripathi P. \& Dubey N.K. 2004. Exploitation of natural products as an alternative strategy to control postharvest fungal rotting of fruit and vegetables. Postharvest Biology and Technology 32:235-245.

39.Zangoei E., Etebarian H. R. \& Sahebani N. 2013. Biological control of gray mold on apple by combining of some yeast and Bacillus subtilis isolates and induction of defense responses. Biological Control of Pests and Plant Disease 2:141-153. 